\title{
URGENSI PENDIDIKAN AGAMA KRISTEN DALAM KRLUARGA
}

\author{
Oleh : Pdt. Dr. Vonny Ells, S.Th., M.Pd.K \\ Pembantu Ketua I Bidang Akademik
}

\begin{abstract}
$\underline{\text { ABSTRAK }}$
Pendidikan Agama Kristen merupakan satu hal yang sangat penting untuk diajarkan kepada semua orang. Pendidikan Agama Kristen bukan suatu pilihan bagi setiap orang tetapi merupakan suatu hal yang sangat penting karena merupakan mandat yang diberikan oleh Allah kepada manusia dengan tujuan agar manusia dapat mengajarkan mengenai kebenaran Allah secara khusus dalam keluarga. Orang tua bertanggung jawab untuk mengajarkan kebenaran Allah kepada anakanak yang merupakan anugerah atau karunia yang diberikan oleh Allah dalam keluarga. Namun sebelum kebenaran Allah diajarkan kepada anak-anaknya maka orang tua yang harus lebih dahulu memahami dan mengaplikasikan kebenaran Allah dalam kehidupan orang tua. Orang Tua harus dapat mendidik anak-anaknya melalui kebenaran firman Allah agar anak-anaknya menjadi anak yang baik dan yang terpenting anak-anaknya dapat mengenal dan percaya kepada Yesus Kristus sebagai Tuhan dan Juruselamat pribadinya.
\end{abstract}

\section{Kata Kunci : Pendidikan Kristen, Mendidik, Keluarga}




\section{A. PENDAHULUAN}

Pendidikan Agama Kristen merupakan suatu keharusan yang harus dilaksanakan bukan suatu pilihan, seperti yang dijelaskan oleh Howard Hendriks, seorang profesor pendidikan Kristen di Seminary Teological Dalas. Howard mengatakan:

Christian education is not an option, it is an order, it is not a luxury, it is a life. It is not something nice to have, it is something nesessary to have. It is not a part of the work the church, it is the work of the church. It is not extraneous, it is essential. It is our obligation, not merely an option. ${ }^{1}$

Pendidikan Kristen bukan pilihan, tetapi suatu perintah; itu bukan merupakan sebuah barang yang mewah, tetapi sebuah kehidupan. Itu bukan sesuatu hal yang bagus sehingga harus dimiliki tetapi suatu kebutuhan yang harus dimiliki. Itu bukan merupakan sebagian dari pekerjaan gereja, tetapi itu adalah pekerjaan gereja. Itu bukan sesuatu hal yang tak ada hubungannya (sampingan), tetapi suatu hal yang utama. Itu kewajiban kita dan bukan pilihan kita.

Oleh karena Pendidikan Agama Kristen itu merupakan suatu keharusan maka otomatis itu merupakan sesuatu yang sangat penting. Ada empat alasan mengapa Pendidikan Agama Kristen itu penting, yaitu yang pertama Pendidikan Agama Kristen itu sangat penting oleh karena Pendidikan Agama Kristen dalam keluarga merupakan perintah dari Allah (Ul. 6:7; Ef. 6:4). Alasan yang kedua ialah karena Pendidikan Agama Kristen dalam keluarga memiliki tujuan yang luar biasa. Alasan yang ketiga, adalah karena Pendidikan Agama Kristen dalam Keluarga memiliki manfaat-manfaat yang besar. Dan yang keempat yaitu karena ada akibat negatif yang kita dapati apabila kita melalaikan Pendidikan Agama Kristen dalam keluarga.

Berikut ini penulis akan menjelaskan beberapa dasar teologi mengenai Pendidikan Agama Kristen dalam keluarga. Penulis menjelaskan tujuan dari Pendidikan Agama Kristen dalam keluarga, juga akan dijelaskan mengenai manfaat-manfaat yang diperoleh jika Pendidikan Agama Kristen tersebut dilaksanakan serta menjelaskan

${ }^{1}$ Howard Hendriks, Christian Education Foundation For The Future (Chicago: Moody Press, 1991), hlm. 12. 
akibat-akibat dari kelalaian dalam melaksanakan Pendidikan Agama Kristen dalam keluarga.

\section{B. DASAR TEOLOGI PENDIDIKAN AGAMA KRISTEN DALAM KELUARGA}

Dalam membahas tentang dasar teologis Pendidikan Agama Kristen dalam keluarga, maka penulis akan membahas baik dalam Perjanjian Lama maupun dalam Perjanjian Baru, di mana nats-nats tersebut menjelaskan tentang mandat yang diberikan Allah kepada keluarga untuk melaksanakan Pendidikan Agama Kristen dalam keluarga mereka.

\section{Mandat Dalam Perjanjian Lama}

Dalam Perjanjian Lama terdapat bagian firman Tuhan yang kaya dan relevan yang berhubungan dengan mendidik anak yaitu dalam Kitab Ulangan 6:1-3 yang berkata:

Inilah perintah, yakti ketetapan dan peraturan, yang aku ajarkan kepadamu atas perintah TUHAN, Allahmu, untuk dilakukan di negeri, ke mana kamu pergi untuk mendudukinya, supaya seumur hidupmu engkau dan anak cucumu takut akan TUHAN, Allahmu, dan berpegang pada segala ketetapan dan perintahNya yang kusampaikan kepadamu, supaya lanjut umurmu. Maka dengarlah, hai orang Israel! Lakukanlah itu dengan setia, supaya baik keadaanmu, dan supaya kamu menjadi sangat banyak, seperti yang dijanjikan TUHAN, Allah nenek moyangmu, kepadamu di suatu negeri yang berlimpahlimpah susu dan madunya.

Dalam ayat ini Musa melanjutkan memberikan penjelasan kepada umat Israel tentang perintah-perintah yang terdapat dalam kitab Ulangan 5:1-22, tentang sepuluh hukum Tuhan. Dalam Ulangan 6:1-3 ini nampak terlihat bahwa Allah memerintahkan untuk semua orang Israel agar dapat melakukan semua ketetapan dan peraturan yang diberikan Allah kepada mereka, dengan tujuan yang pertama supaya bangsa Israel dan keturunan mereka takut akan Tuhan (Ul. 6:2a). 
Tujuan kedua ialah supaya lanjut umur mereka (U1. 2:2b). Tujuan ketiga supaya baik keadaan mereka dan bertambah banyak (U1. 6:3).

Semua ketetapan dan perintah yang dijelaskan dalam kitab Ulangan 5:1-22 itu juga harus diajarkan kepada anak-anak mereka. Tetapi Musa lebih dahulu menegaskan bahwa bangsa Israel, khususnya orang tua, harus sungguh-sungguh mengasihi Allah lebih dahulu, karena kasih Allah adalah perintah yang utama dan juga hukum yang terutama dan yang pertama (Mat. 22:37-38). Baru setelah orang tua mengasihi Allah, mereka harus mengajarkan anak-anak mereka tentang kasih kepada Allah tersebut, seperti yang terlihat dalam Ulangan 6:4-7 yang berkata:

Dengarlah, hai orang Israel: TUHAN itu Allah kita, TUHAN Esa! Kasihilah TUHAN, Allahmu dengan segenap hatimu dan dengan segenap jiwamu dan dengan segenap kekuatanmu. Apa yang kuperintahkan kepadamu pada hari ini haruslah engkau perhatikan, haruslah engkau mengajarkannya berulang-ulang kepada anak-anakmu dan membicarakannya apabila engkau duduk di rumahmu, apabila engkau sedang dalam perjalanan, apabila engkau berbaring dan apabila engkau bangun.

Kalau kita perhatikan nats tersebut di atas, maka dapat dikatakan bahwa pada dasarnya Musa sedang berbicara dengan para orang tua mengenai hubungan orang tua dengan Tuhan mereka. Orang tua harus mengasihi Tuhan Allah dengan segenap hati dan jiwa serta kekuatan mereka, sebelum mereka mengajar anak-anak mereka. Karena sebelum mengajar kasih Allah kepada anak-anak mereka, orang tua harus sudah lebih dahulu mengasihi Allah dan mempunyai hidup yang benar secara rohani sehingga dapat mendidik dan mengajar dengan baik dan berhasil. Itu sebabnya Musa berkata dengan tegas, "Apa yang kuperintahkan kepadamu pada hari ini haruslah engkau perhatikan" (U1. 6:6).

Salah satu cara utama untuk mengungkapkan kasih kepada Allah (Ul. 6:5) ialah memperdulikan kesejahteraan rohani anak-anak kita dan berusaha menuntun mereka kepada hubungan yang setia dengan Allah. Dikatakan demikian oleh karena pembinaan rohani anak-anak seharusnya merupakan perhatian utama semua orang tua. Juga pengarahan rohani harus berpusat di dalam rumah, dan melibatkan ayah dan ibu. Pengabdian kepada Allah di dalam rumah tangga wajib dilakukan; hal itu adalah perintah langsung dari Tuhan (Ul. 6:7-9). 
Tujuan dari pengarahan orang tua ialah mengajar anak-anak untuk takut akan Tuhan, berjalan pada jalan-Nya, mengasihi dan menghargai Dia, serta melayani Dia dengan segenap hati dan jiwa. Oleh sebab itu orang percaya harus dengan tekun memberikan kepada anak-anaknya pendidikan yang berpusatkan Allah di mana segala sesuatu dihubungkan dengan Allah dan jalan-jalan-Nya. ${ }^{2}$

Dalam mengajar anak-anak mereka tentang kasih Allah itu, orang tua harus mengajar dengan rajin dan sepenuh hati. Ini terlihat di mana Musa menegaskan bahwa ajaran itu harus berulang-ulang diajarkan dan dibicarakan di kala duduk, dalam perjalanan, berbaring dan apabila bangun (Ul. 6:7). Dan apabila pengajaran itu dilaksanakan dengan rajin dan sepenuh hati maka ajaran itu akan dapat dijalankan dengan berhasil juga. Inilah tugas yang sangat penting yang berulang-ulang diperintahkan Allah di dalam Alkitab, seperti juga yang tertulis di dalam Ulangan 11:18-20:

Tetapi kamu harus menaruh perkataanku ini dalam hatimu dan dalam jiwamu; kamu harus mengikatkannya sebagai tanda pada tanganmu dan haruslah itu menjadi lambang di dahimu. Kamu harus mengajarkannya kepada anak-anakmu dengan membicarakannya, apabila engkau duduk di rumah dan apabila engkau sedang dalam perjalanan, apabila engkau berbaring dan apabila engkau bangun; engkau harus menuliskannya pada pintu rumahmu dan pada pintu gerbangmu.

Juga di dalam Amsal 22:6 dan Amsal 29:17, Salomo berkata: Didiklah orang muda menurut jalan yang patut baginya, maka pada masa tuanyapun ia tidak akan menyimpang dari pada jalan itu. Didikalah anakmu, maka ia akan memberikan ketentraman kepadamu dan mendatangkan sukacita kepadamu.

Dalam kedua ayat tersebut di atas dijelaskan bahwa orang tua harus mendidik anak-anaknya. Didikan itu harus menurut jalan yang patut baginya. Adapun didikan menurut "jalan yang patut baginya" yaitu dengan cara mengajarkan prinsip-prinsip atau perintah-perintah Allah di dalam keluarga.

Orang tua harus mengabdikan diri mereka untuk memberikan didikan disiplin roahni kepada anak-anak mereka. Kata Ibrani untuk

${ }^{2}$ Donald C. Stamps, Alkitab Penuntun Hidup Berkelimpahan, pen., Nugroho Hananiel (Malang: Gandum Mas, 2003), hlm. 285. 
"mendidik" berarti "mengabdikan." Jadi, didikan Kristen bertujuan mengabdikan anak-anak kita kepada Allah dan kehendak-Nya. Ini tercapai dengan memisahkan mereka dari pengaruh-pengaruh jahat dunia dan mengajar mereka berperilaku saleh. Akar kata yang sama juga bisa berarti "memberi atau meningkatkan kegemaran akan," orang tua harus mendorong anak-anak mereka agar mereka sendiri mencari Allah dan dengan demikian dapat menikmati pengalaman-pengalaman rohani yang takkan mereka lupakan. Kata "ia tidak akan menyimpang daripada jalan itu." Ini berarti bahwa seorang anak yang telah dididik dengan benar tidak akan menyimpang dari jalan saleh yang telah diajarkan orang tuanya. ${ }^{3}$

Jadi mengajar Pendidikan Agama Kristen dalam keluarga merupakan tanggung jawab bahkan merupakan kewajiban yang diberikan Allah kepada orang tua Kristen, karena itu kewajiban maka harus dilaksanakan.

Apabila tanggung jawab tersebut sudah dijalankan maka firman Tuhan berjanji bahwa anak-anak itu tidak akan menyimpang dari apa yang telah mereka dengar dari ajaran orang tua mereka dan anak-anak itu juga akan memberikan ketenteraman serta mendatangkan sukacita bagi orang tua. Dan terlebih lagi anak-anak itu dapat mengikuti perintah atau hukum-hukum Tuhan dan dapat menghadapi tantangantantangan dalam hidup ini. Seperti yang dijelaskan oleh para Navigator dalam buku Orang Tua dan Anak bahwa: "Apabila kita mendidik anakanak kita sejak awalnya maka kita telah menolong dan membimbing mereka untuk hidup di dalam Tuhan serta mempersiapkan mereka sungguh-sungguh mengenal Tuhan... dan dapat menghadapi tantangan hidup ini.",4

Dalam ayat-ayat yang telah dijelaskan di atas bahwa jelas sekali terlihat oleh kita bahwa Allah menghendaki agar perintah atau hukumhukum Tuhan yang pada masa ini disebut dengan Pendidikan Agama Kristen itu dilaksanakan di dalam keluarga. Dan oleh karena Pendidikan Agama Kristen itu sesuatu yang penting dan harus untuk dilaksanakan, maka tidak ada alasan bagi keluarga-keluarga Kristen untuk tidak melaksanakannya.

${ }^{3}$ Stamps, Alkitab Penuntun Hidup Berkelimpahan, hlm. 994.

${ }^{4}$ Para Navigator, Orang Tua dan Anak-anak (Bandung: Yayasan Kalam Hidup, 1980), hlm. 64. 


\section{Mandat Dalam Perjanjian Baru}

Dalam Perjanjian Baru, mandat Allah tentang pendidikan itu dapat kita lihat terutama dalam surat rasul Paulus yang terdapat di dalam Efesus 6:4 yang berkata: "Dan kamu bapa-bapa, janganlah bangkitkan amarah di dalam hati anak-anakmu, tetapi didiklah mereka di dalam ajaran dan nasihat Tuhan."

Dalam ayat di atas, penulis perhatikan bahwa ada dua perintah yang diberikan kepada orang tua khususnya bapa-bapa. Perintah tersebut adalah, yang pertama, jangan menyakiti hati anak-anak sehingga membuat mereka menjadi marah. Dan perintah yang kedua adalah perintah untuk mendidik anak-anak mereka.

Kewajiban yang penting dari para orang tua ialah memberikan kepada anak mereka ajaran dan teguran yang termasuk pengasuhan Kristen. Orang tua harus menjadi teladan dalam kehidupan dan perilaku Kristen, serta lebih mempedulikan keselamatan anak mereka daripada pekerjaan, profesi, pelayanan mereka di gereja atau kedudukan sosial mereka. Menurut perkataan Paulus dalam ayat tersebut di atas, maka orang tua harus bertanggung jawab untuk memberi asuhan dan didikan kepada anak mereka yang akan mempersiapkan mereka untuk hidup berkenan kepada Allah. Yang terutama bertanggung jawab memberikan didikan Alkitabiah dan rohani kepada anak-anak adalah keluarga, bukan gereja atau Sekolah Minggu. Gereja dan Sekolah Minggu hanya membantu didikan dari orang tua. Inti pengasuhan Kristen ialah: hati bapa harus berpaling kepada hati anaknya agar dapat membawa hati anak itu kepada hati Juruselamat. ${ }^{5}$

Menurut Warren W. Wiersbe, kata asli didiklah (bahasa Yunani: Ektrefete) yang diterjemahkan menjadi "mendidik" yang terlihat dalam ayat 4 di atas, sama dengan kata yang terdapat dalam Efesus 5:29 yang diterjemahkan menjadi "mengasuh" (bahasa Yunani: ektrefetei). Di mana orang tua harus mendidik anak-anaknya dengan mengasihi dan memberikan dorongan di dalam Tuhan. Tidak cukup kalau ia hanya membesarkan atau memelihara anak-anak secara jasmani tetapi juga harus memelihara mereka secara emosional dan spiritual. ${ }^{6}$ Orang tua harus mengasuh anak-anak dalam segala hal, baik itu dalam hal

${ }^{5}$ Stamps, Alkitab Penuntun Hidup Berkelimpahan, hlm. 1994.

${ }^{6}$ Warren W. Wiersbe, Kaya Di Dalam Kristus (Bandung: Yayasan Kalam Hidup, t.t), hlm. 146. 
memenuhi kebutuhan jasmani mereka dan memenuhi kebutuhan rohani mereka, dan kedua hal ini harus dipenuhi oleh orang tua.

Selanjutnya Wiersbe menjelaskan bahwa kata "didiklah" (bahasa Yunani: Paideia) juga mengandung arti belajar melalui disiplin. Kata ini diterjemahkan menjadi menghajar dalam Ibrani 12. Di mana orang tua harus mendisiplin anak-anak mereka. Mendisiplin di sini bukan berarti tidak mengasihi mereka tetapi disiplin merupakan prinsip kehidupan yang sangat penting dan itu merupakan suatu bukti kasih, itu dapat kita lihat dalam Ibrani 12:6 dan Amsal 13:24 yang berkata: "Tuhan menghajar orang yang dikasihi-Nya... Siapa mengasihi anaknya menghajar dia pada waktunya."7

Arti kata "nasehat" (bahasa Yunani: nouthesia) dalam ayat tersebut di atas mengandung arti bahwa orang tua harus mengajar dan mendidik anak-anak mereka. Dalam mendidik anak, orang tua tidak hanya menggunakan tindakan untuk mendidik anak, tetapi juga melalui katakata dan tentu saja ajaran orang tua harus selalu berkaitan dengan firman Tuhan. ${ }^{8}$

Berdasarkan penjelasan tersebut maka dapat diambil kesimpulan bahwa orang tua harus mengasuh atau mendidik anak-anak itu di dalam disiplin dan nasehat Tuhan. Nasehat ini berupa pendidikan lisan atau koreksi yang diberikan atau dengan kata lain memperingati. Hal ini jelas sekali terlihat dalam terjemahan versi New English Bible: "You Fathers, again, must not goad your children to resentment, but give them the instruction, and the correction, which belong to a Christian upbringing." Yang berarti, "Kamu bapa-bapa, sekali lagi, janganlah mendorong anak-anakmu kepada kemarahan, melainkan memberi kepada mereka baik pendidikan maupun koreksi yang berkaitan dengan pengasuhan Kristen."

Jelas sekali bahwa di dalam keluargalah tempat di mana anak-anak belajar mengenai Tuhan dan kehidupan Kristen. Untuk itulah sudah waktunya orang tua Kristen mulai mendidik anak-anak mereka dan untuk melaksanakan Pendidikan Agama Kristen dalam keluarga mereka.

${ }^{7}$ Wiersbe, Kaya Di Dalam Kristus, hlm. 146.

${ }^{8}$ Ibid., hlm. 147.

9 , Eight Translation New Testement (Wheaton Illinois: Tyndale House Publishers, 1974), hlm. 1415. 


\section{TUJUAN PENDIDIKAN AGAMA KRISTEN DALAM KELUARGA}

Menurut Verkuyl, tujuan Pendidikan Agama Kristen adalah supaya anak-anak itu menjadi pengikut teladan Yesus supaya mereka menjadi serupa dengan teladan Yesus Kristus. Seperti yang juga dikatakan dalam firman Tuhan di Roma 8:29, yang berbunyi: "Sebab semua orang yang dipilihNya dari semula, mereka juga ditentukanNya dari semula untuk menjadi serupa dengan gambaran AnakNya, supaya Ia, AnakNya itu, menjadi yang sulung di antara banyak saudara."10

Sedangkan Homrig Hausen dan Enklaar menjelaskan bahwa tujuan Pendidikan Agama Kristen itu secara terperinci sebagai berikut:

Pertama untuk memimpin murid selangkah demi selangkah kepada pengenalan yang sempurna mengenai peristiwaperistiwa yang terdapat dalam Alkitab dan pengajaranpengajaran yang diberitakan olehnya. Kedua membimbing murid dalam cara menggunakan kebenaran-kebenaran asasi Alkitab itu untuk keselamatan seluruh hidupnya, dan ketiga mendorong murid tersebut mempraktekkan asas-asas dasar Alkitab itu, supaya membina suatu perangai Kristen yang kukuh. Serta meyakinkannya, supaya mengakui bahwa kebenaran dan asas-asas itu menunjukkan jalan untuk pemecahan masalah-masalah kesusilaan, sosial dan politik di dunia ini. ${ }^{11}$

Melihat akan uraian mengenai tujuan Pendidikan Agama Kristen di atas, maka dapat disimpulkan bahwa tujuan Pendidikan Agama Kristen itu sangat luas yaitu di mana anak itu bukan saja mengerti akan kebenaran firman Tuhan tetapi juga anak itu dapat mengambil keputusan untuk memperoleh keselamatan yang dinyatakan dalam kebenaran firman Tuhan yang telah dimengerti dan terlebih lagi dapat mempraktekkannya dalam kehidupan sehari-hari sehingga ia juga bisa menjadi garam dan terang bagi keluarga maupun lingkungannya serta mampu menghadapi tantangan-tantangan hidup ini.

${ }^{10}$ J. Verkuyl, Etika Kristen (Jakarta: BPK Gunung Mulia, 1989), hlm. 177.

${ }^{11}$ E. G. Homrig Hausen \& I. H. Eklaar, Pendidikan Agama Kristen (Jakarta: BPK Gunung Mulia, 1989), hlm. 50. 
Jadi apabila Pendidikan Agama Kristen itu dilaksanakan dengan baik dalam keluarga, maka keluarga tersebut akan mencapai tujuan Pendidikan Agama Kristen tersebut dan apabila tujuan itu telah tercapai maka keluarga tersebut akan memperoleh manfaat atau hasil dari apa yang dilaksanakannya. Dengan kata lain bahwa manfaat yang diperoleh itulah yang menunjukkan bahwa tujuan Pendidikan Agama Kristen itu telah dicapai oleh keluarga yang telah melaksanakannya.

\section{MANFAAT PENDIDIKAN AGAMA KRISTEN DALAM KELUARGA}

Adapun manfaat-manfaat yang diperoleh apabila Pendidikan Agama Kristen itu dilaksanakan di dalam keluarga adalah sebagai berikut:

\section{Anak Dapat Mengenal Dan Percaya Akan Tuhan Yesus}

Manfaat yang pertama, anak-anak itu dapat mengenal dan percaya akan Tuhan Yesus dan memperoleh keselamatan. Ruth Laufer mengatakan bahwa keselamatan diperoleh oleh anak dengan cara menerima apa yang Tuhan sediakan. Oleh karena untuk seorang anak tidak kesulitan menerima sesuatu. Sehingga pada waktu seorang anak mendengar dan mengerti tentang kasih Allah, yang sudah mengirim Tuhan Yesus karena dosanya, maka anak itu juga dapat membuka hati dan menerima keselamatan yang disediakan bagi anak tersebut. ${ }^{12}$

\section{Anak Tidak Menyimpang Dari Apa Yang Diajarkan Firman Tuhan}

Manfaat yang kedua jika Pendidikan Agama Kristen itu dilaksanakan yaitu di mana anak-anak tersebut tidak akan meninggalkan didikan orang tuanya dan tidak menyimpang dari jalan yang diajarkan dalam firman Tuhan. Karena anak tersebut dapat mempertahankan kelakuan mereka yang bersih jika mereka terus

\footnotetext{
${ }^{12}$ Ruth Laufer, Pedoman Pelayanan Anak (Batu Malang: Yayasan Persekutuan Pekabaran Injil Indonesia Departemen Pembinaan Anak dan Pemuda, 1983), hlm. 10.
} 
mendengar pengajaran orang tua melalui firman Tuhan. Seperti kata firman Tuhan dalam Mazmur 119:9 berkata: "Dengan apakah seorang muda mempertahankan kelakuannya bersih? Dengan menjaganya sesuai dengan firman-Mu."

Tetapi seringkali kita takut bahwa anak yang percaya akan Tuhan Yesus tidak tetap iman mereka. Tetapi sesuai dengan firman Tuhan di dalam Amsal 22:6 yang berkata: "Didiklah orang muda menurut jalan yang patut baginya, maka pada masa tuanya pun ia tidak akan menyimpang dari jalan itu." Di dalam ayat ini Tuhan berjanji bahwa anak yang diajarkan jalan Tuhan tidak akan menyimpang dari padanya pada masa tuanya. ${ }^{13}$

Juga seperti yang dijanjikan Tuhan dalam kitab Yesaya 55:11 yang berkata: "Demikianlah firman-Ku yang keluar dari mulut-Ku: ia tidak akan kembali kepada-Ku dengan sia-sia, tetapi ia akan melaksanakan apa yang Kukehendaki, dan akan berhasil dalam apa yang Kusuruhkan kepadanya." Firman Tuhan akan terus berbicara di dalam hati anak sehingga ia mampu untuk mempertahankan kehidupan yang bersih dan tidak akan menyimpang dari jalan yang diajarkan dalam firman Tuhan.

\section{Anak Akan Bertindak Hati-hati Sesuai Dengan Firman Tuhan}

Manfaat yang ketiga adalah anak tersebut akan bertindak hati-hati sesuai dengan firman Tuhan yang telah diterimanya dari ajaran orang tua dan kehidupan keluarga tersebut akan berhasil dan beruntung ke manapun kita akan pergi, seperti yang dijelaskan dalam Yosua 1:7 dan 8 yang berkata:

Hanya, kuatkan dan teguhkanlah hatimu dengan sungguhsungguh, bertindaklah hati-hati sesuai dengan seluruh hukum yang telah diperintahkan kepadamu oleh hamba-Ku Musa; janganlah menyimpang kekanan atau kekiri, supaya engkau beruntung, ke manapun engkau pergi. Jangan engkau lupa memperkatakan kita Taurat ini, tetapi renungkanlah itu siang dan malam, supaya engkau bertindak hati-hati sesuai dengan segala yang tertulis di dalamnya, sebab dengan demikian perjalananmu akan berhasil dan engkau akan beruntung.

\footnotetext{
${ }^{13}$ Laufer, Pedoman Pelayanan Anak, hlm. 11.
} 


\section{Anak Dapat Memuliakan Allah}

Manfaat yang keempat adalah anak-anak dapat memuliakan Allah, apabila kita sebagai orang tua dapat memperkenalkan Tuhan Yesus kepada anak-anak maka reaksi mereka ketika mengetahui perbuatan Allah yang sungguh luar biasa dalam hidupnya adalah dengan langsung mereka dapat memuliakan Allah. Anak kecil lebih spontan dalam hal menyanyi dan memuji Tuhan dari pada orang dewasa. Pujian dari hati anak berkenan kepada Bapa di sorga, seperti yang tertulis dalam Mazmur 8:3 dan Matius 21:15-16, demikian:

Dari mulut bayi-bayi dan anak-anak yang menyusu telah Kauletakkan dasar kekuatan karena lawan-Mu, untuk membungkamkan musuh dan pendendam.(Mzm. 8:3). Tetapi ketika imam-imam kepala dan ahli-ahli Taurat melihat mujizatmujizat yang dibuat-Nya itu dan anak-anak yang berseru dalam Bait Allah: "Hosana bagi Anak Daud!" hati mereka sangat jengkel, lalu mereka berkata kepada-Nya: "Engkau dengar apa yang dikatakan anak-anak ini?" kata Yesus kepada mereka: "Aku dengar; belum pernahkan kamu baca: Dari mulut bayibayi dan anak-anak yang menysus Engkau telah menyediakan puji-pujian?"

\section{Anak Dapat Menjadi Garam Dan Terang Bagi Dunia Sekitarnya}

Manfaat yang kelima apabila Pendidikan Agama Kristen itu dilaksanakan dalam keluarga yaitu anak tersebut dapat menjadi garam dan terang dunia bagi masyarakat, negara bahkan bagi generasi yang akan datang. Apabila nanti kelak anak itu bekerja dalam pemerintahan, anak itu dapat membawa berkat bagi masyarakat karena kehidupannya yang jujur dan bertanggung jawab. Seperti yang terlihat dalam kehidupan Ester yang mana melalui dia bangsa Yahudi diselamatkan. Juga melalui Daniel, raja dan bangsa kafir mengenal Allah, melalui Yusuf bangsa kafir diselamatkan dan ia menyelamatkan bangsa Mesir dari kelaparan. Ini semua oleh karena semenjak kecil mereka diajarkan hukum Tuhan atau Firman Tuhan di dalam keluarga mereka. ${ }^{14}$

\footnotetext{
${ }^{14}$ Laufer, Pedoman Pelayanan Anak, hlm. 12.
} 
Melihat akan manfaat-manfaat yang besar yang akan diperoleh maka seharusnya keluarga-keluarga Kristen pada masa kini lebih lagi bersemangat dan bersungguh-sungguh dalam melaksanakan Pendidikan Agama Kristen di dalam keluarganya.

\section{E. AKIBAT JIKA PENDIDIKAN AGAMA KRISTEN DALAM KELUARGA DIABAIKAN}

Apabila kita melakukan Pendidikan Agama Kristen maka kita akan memperoleh banyak manfaat di dalamnya, tetapi jika kita mengabaikannya maka akan ada akibat negatif yang akan diperoleh. Dalam Alkitab ada beberapa contoh keluarga yang tidak sungguhsungguh melaksanakan Pendidikan Agama Kristen. Pertama, dapat dilihat dalam kehidupan Imam Eli, di mana walaupun ia seorang imam tetapi firman Tuhan katakan bahwa anak-anaknya adalah orang-orang dursila yang tidak mengindahkan Tuhan. Anak-anak Eli menjadi jahat dan disebut orang-orang dursila oleh karena Eli tidak mendidik mereka dengan baik. Padahal ia telah membesarkan Samuel dengan baik.

Bekker mengatakan bahwa Eli bukan seorang yang tegas dan kuat. Sehingga kedua anaknya, yaitu Hofni dan Pinehas, dibiarkan saja berbuat jahat. Memang betul Eli menegur kedua anaknya, tetapi ia tidak menghukum mereka, sehingga makin hari makin menjadi nyata. ${ }^{15}$

Akibat dari semuanya itu Allah menghukum keluarga Eli, seperti yang terdapat dalam 1 Samuel 3: 13 yang berkata: "Sebab telah Kuberitahukan kepadanya, bahwa Aku akan menghukum keluarganya untuk selamanya karena dosa yang telah diketahuinya, yakni bahwa anak-anaknya telah menghujat Allah, tetapi ia tidak memarahi mereka.!"

Adapun bentuk hukuman yang Allah berikan bagi kedua anak Eli, yaitu keduanya tidak hidup lama, karena Tuhan akan mematikan mereka, dan itu terbukti di mana akhirnya kedua anak itu tewas dalam pertempuran melawan orang Filistin (1 Sam. 2:25c; 4:11).

Bagi Eli sendiri bentuk hukuman yang dialami yaitu Eli juga mati akibat jatuh dari kursi dan lehernya patah (1 Sam. 4:18). Dan tidak ada keturunannya yang menggantikan dia sebagai imam oleh karena semua

${ }^{15}$ F. L. Bakker, Sejarah Kerajaan Allah (Jakarta: BPK Gunung Mulia, 1996), hlm. 2:459. 
keturunannya mati terbunuh (1 Sam. 2:31, 33). Seperti yang dijelaskan Bekker bahwa karena dosa-dosa Eli maka segala orang laki-laki dari keturunan Eli akan mati pada masa akil baliq. Dan pangkat imam besar akan diserahkan kepada orang lain. Nubuatan itu terjadi kemudian pada waktu imam-imam di Nob dibunuh oleh Raja Saul (1 Sam. 22). ${ }^{16}$

Oleh karena perbuatan-perbuatan anak-anak Eli, maka bangsa Israel juga ikut melakukan pelanggaran dan melakukan apa yang jahat di mata Tuhan dan Tuhan menghukum bangsa Israel, yaitu bangsa Israel kalah melawan orang Filistin dan tabut Tuhan dirampas oleh orang Filistin (1 Sam. 4:10,17). Contoh yang lain dapat kita lihat juga di dalam Hakim-hakim 2:6-15, dimana dijelaskan bahwa setelah Yosua mati dan angkatan pada masa Yosua mati, maka bangkitlah angkatan yang lain yang tidak mengenal Tuhan, dan orang Israel melakukan apa yang jahat di mata Tuhan (Hak. 2:8-11).

Ini menunjukkan bahwa angkatan-angkatan pada masa Yosua mengabaikan pengajaran tentang perintah-perintah Tuhan dan perbuatan-perbuatan yang besar yang dilakukan Tuhan kepada keturunan mereka, sehingga akhirnya angkatan sesudah mereka sungguh-sungguh tidak mengenal Tuhan dan melakukan yang jahat di mata Tuhan. Seperti yang dikatakan dalam Hakim-hakim 2:10-11:

Setelah seluruh angkatan itu dikumpulkan kepada nenek moyangnya, bangkitlah sesudah mereka itu angkatan yang lain, yang tidak mengenal TUHAN ataupun perbuatan yang dilakukan-Nya bagi orang Israel. Lalu orang Israel melakukan apa yang jahat di mata TUHAN dan mereka beribadah kepada para Baal.

Akhirnya Tuhan menjadi marah atas perbuatan mereka dan menghukum mereka (Hak. 2:14-15). Adapun bentuk hukuman yang Tuhan berikan yaitu Tuhan menyerahkan mereka ke tangan perampok dan menjual mereka kepada musuh mereka oleh karena tangan Tuhan selalu melawan mereka dan mendatangkan malapetaka kepada mereka (Hak. 2:14-15).

Contoh yang ketiga dapat kita lihat dari kehidupan keluarga Samuel, di mana anak-anak Samuel juga sama seperti anak-anak Eli yang hidup tidak sesuai dengan Firman Tuhan dan berlaku jahat dengan sering berbuat dosa di mata Tuhan yaitu mereka selalu mengejar laba

${ }^{16}$ Bakker, Sejarah Kerajaan Allah, hlm. 2:461. 
dan menerima suap dan memutarbalikkan keadilan, seperti yang dikatakan dalam 1 Samuel 8:3 yakni: "Tetapi anak-anaknya itu tdak hidup seperti ayahnya; mereka mengejar laba, menerima suap dan memutarbalikkan keadilan."

Anak-anak Samuel menjadi orang-orang jahat. Itu mungkin disebabkan oleh karena Samuel terlalu mementingkan pelayanan keluar dan mengabaikan pelayanan dalam keluarganya sendiri, ia sibuk melayani orang lain dari pada keluarganya sendiri. ${ }^{17}$

Akibat dari kejahatan anak-anak Samuel, bangsa Israel meminta seorang raja dan menolak Tuhan sebagai raja mereka. Seperti yang dikatakan dalam Ensiklopedia Umum: "Akibat dari kejahatan anakanaknya itu menyebabkan adanya ketidakpuasan bangsa Israel terhadap sistem pemerintahan hirarki dan menuntut sistem yang lain yaitu sistem monarki, di mana harus ada seorang raja." 18

Dari ketiga contoh firman Tuhan ini maka dapat disimpulkan bahwa ada akibat yang fatal jika kita tidak mengajarkan hukum-hukum Tuhan dan perbuatan Tuhan yang besar kepada anak. Atau dengan kata lain ada akibat buruk jik kita tidak mengajarkan Pendidikan Agama Kristen di dalam keluarga, akibat-akibat itu adalah:

\section{Bagi Anak Itu Sendiri}

Pertama-tama anak itu sendiri tidak akan mengenal Tuhan dan tidak percaya kepada Tuhan dan akhirnya hidupnya jauh dari jalanjalan Tuhan serta melakukan hal-hal yang jahat di mata Tuhan dan tidak dapat memuliakan Allah dalam kehidupannya setiap hari.

Kedua, karena mereka menyimpang dari jalan Tuhan, maka Tuhan tidak memberkati dan bahkan menghukum mereka. Seperti Hofni dan Pinehas serta keturunan Yosua yang hidup jauh dari ketetapan Tuhan maka Tuhan juga akan menghukum anak yang melakukan kejahatan. Telah dijelaskan di atas bahwa kedua anak Eli mati karena pelanggarannya. Keturunan Yosua diserahkan kepada perampok dan dijual kepada musuh, serta Tuhan sendiri melawan dan mendatangkan

17 _ Hebrew, Greek Key Study Bible, Strong's Dictionary Concordance Vocabulary (AMG Publishers, t.t), hlm. 376.

$18 \ldots$ Ensiklopedia Alkitab Masa Kini (Jakarta: Yayasan Komunikasi Bina Kasih/OMF, 1997), hlm. 2:376. 
malapetaka kepada mereka karena hati mereka yang jauh dari Tuhan atau tidak mengenal Allah (1 Sam. 2:25c; 14:11; Hak. 2:14-15).

\section{Akibat Bagi Keluarga Itu Sendiri}

Pendidikan Agama Kristen yang diabaikan dalam keluarga bukan saja berakibat buruk bagi anak itu sendiri, tetapi juga bagi keluarga itu. Keluarga akan mendapat malu akibat dari perbuatan anak-anaknya yang tidak sesuai dengan firman Tuhan dan akan mendapat banyak masalah di dalam keluarga dan kehidupan keluarga tidak akan berhasil dan beruntung serta bahagia.

Dalam kitab Amsal dijelaskan bahwa apabila anak itu tidak menuruti firman Tuhan yang merupakan akibat dari orang tua yang mengabaikan pengajaran rohani, maka ayah dan ibunya akan menjadi dukacita dan menjadi sakit hati serta mendatangkan bencana bagi keluarga tersebut. Seperti yang dijelaskan dalam kitab Amsal yang berkata:

Anak yang bijak mendatangkan sukacita kepada ayahnya, tetapi anak yang bebal adalah kedukaan bagi ibunya. Anak yang bijak menggembirakan ayahnya, tetapi orang yang bebal menghina ibunya. Anak yang bebal menyakiti hati ayahnya... anak yang bebal adalah bencana bagi ayahnya. (Ams. 10:1; 15:20; 17:25a; 19:13a).

Dalam kasus keluarga Eli, bukan saja nama buruk yang mereka terima, tetapi hukuman Allah juga menimpa Eli sebagai orang tua karena mengabaikan pengajaran rohani. Adapun hukuman yang diterima oleh Eli yaitu Eli sendiri mati dan tidak ada keturunannya yang menggantikan dia sebagai imam oleh karena semua keturunannya mati terbunuh (1 Sam. 2:13, 33). Bisa jadi seperti hukuman yang ditimpa oleh Eli, maka Allah juga akan menghukum keluarga yang tidak melaksanakan Pendidikan Agama Kristen di dalam keluarganya.

\section{Akibat Bagi Masyakarat Luas}

Bukan saja ada akibat bagi anak dan keluarga, tetapi juga bagi masyarakat luas. Di dalam masyarakat anak itu tidak dapat menjadi garam dan terang, tetapi malah menjadi anak yang dapat merusakkan 
dan mengganggu kehidupan masyarakat di sekitarnya. Seperti kejahatan yang dilakukan kedua anak Eli membuat bangsa Israel mengikuti melakukan pelanggaran kepada Tuhan maka kemungkinan besar juga masyarakat di sekitar anak itu bisa mengikuti perbuatan anak yang jahat itu, dan akhirnya masyarakat akan hidup tidak tenteram akibat dari perbuatannya. Melihat akan akibat-akibat buru tersebut di atas maka seharusnya ini menjadi pendorong bagi keluarga-keluarga Kristen untuk melaksanakan Pendidikan Agama Kristen di dalam keluarga dengan serius.

\section{DAFTAR PUSTAKA}

Alkitab. Jakarta: Lembaga Alkitab Indonesia, 2015.

Bakker, F. L. Sejarah Kerajaan Allah. Jilid 2. Jakarta: BPK Gunung Mulia, 1996.

Eight Translation New Testement. Wheaton Illinois: Tyndale House Publishers, 1974.

, Ensiklopedia Alkitab Masa Kini. Jilid. 2. Jakarta: Yayasan Komunikasi Bina Kasih/OMF, 1997.

Hartono, Handreas. "Kurikulum PAK Yang Kontekstual Bagi Usia Lanjut Dan Aktual.” KURIOS (Jurnal Teologi dan Pendidikan Agama Kristen) 1, no. 1 (2013): 11-21.

Hasugian, Johanes Waldes. Menjadi Guru PAK Profesional Melalui Supervisi Pendidikan Agama Kristen. 2nd ed. Medan: CV. Mitra, 2016.

Hasugian, Johanes Waldes. Strategi Belajar Mengajar Pendidikan Agama Kristen Yang Efektif. Prodi Teologi STT-SU, 2016.Hausen, E. G. Homrig \& I. H. Eklaar. Pendidikan Agama Kristen. Jakarta: BPK Gunung Mulia, 1989.

Hendra, Vitaurus. "Peran Orang Tua Dalam Menerapkan Kasih Dan

Disiplin Kepada Anak Usia 2-6 Tahun Sebagai Upaya

Pembentukkan Karakter.” KURIOS (Jurnal Teologi dan

Pendidikan Agama Kristen) 3, no. 1 (2015): 48-65.

www.sttpb.ac.id/e-journal/index.php/kurios. 
Hebrew, Greek Key Study Bible, Strong's Dictionary Concordance Vocabulary. AMG Publishers, t.t.

Howard, Hendriks. Christian Education Foundation For The Future. Chicago: Moody Press, 1991.

Laufer, Ruth. Pedoman Pelayanan Anak. Batu Malang: Yayasan Persekutuan Pekabaran Injil Indonesia Departemen Pembinaan Anak dan Pemuda, 1983.

Navigator, Para. Orang Tua Dan Anak-anak. Bandung: Yayasan Kalam Hidup, 1980.

Pasuhuk, Novie D S. "Pendidikan Keluarga Yang Efektif.” KURIOS (Jurnal Teologi dan Pendidikan Agama Kristen) 2, no. 1 (2014): 70-81. www.sttpb.ac.id/e-journal/index.php/kurios.

Stamps, Donald C. Alkitab Penuntun Hidup Berkelimpahan. Diterjemahkan oleh Nugroho Hananiel. Malang: Gandum Mas, 2003.

Siahaan, Harls Evan Rianto. "Hikmat Sebagai Implikasi Pendidikan Kristiani Dalam Keluarga: Refleksi 1 Raja-Raja 3:1-15." DUNAMIS (Jurnal Teologi dan Pendidikan Kristiani) Vol 1, no. 1 (2016): 15-30. www.sttintheos.ac.id/ejournal/index.php/dunamis.

Verkuyl, J. Etika Kristen. Jakarta: BPK Gunung Mulia, 1989.

Wiersbe, Warren W. Kaya Di Dalam Kristus. Bandung: Yayasan Kalam Hidup, t.t. 